\title{
PENGARUH WORD OF MOUTH DAN LOKASI TERHADAP KEPUTUSAN MENGAMBIL KREDIT DI LEMBAGA PERKREDITAN DESA "MARTO NUGROHO" DESA ROWOMARTO KECAMATAN PATIANROWO KABUPATEN NGANJUK
}

\author{
Dhiyan Septa Wihara \\ Universitas Nusantara PGRI Kediri \\ Email:dhiyansepta@unpkediri.ac.id
}

\section{Kata kunci:}

Word of Mouth, Lokasi, Keputusan pengambilan kredit, Lembaga perkreditan desa "marto nugroho"

Keywords:

Word of Mouth, Location, Decision on taking credi, Village Creit Institution "Marto Nugroho"

Dhiyan Septa Wihara. (2019). Pengaruh Word Of Mouth Dan Lokasi Terhadap Keputusan Mengambil Kredit Di Lembaga Perkreditan Desa "Marto Nugroho" Desa Rowomarto Kecamatan Patianrowo Kabupaten Nganjukr. Akuntabilitas: Jurnal Ilmu-Ilmu Ekonomi, 12(1), 15-27. https://doi.org/10.35457/akuntabilitas.v1 $2 i 1.720$

\begin{abstract}
ABSTRAK
Penelitian ini bertujuan untuk 1) Menganalisis pengaruh word of mouth terhadap keputusan pengambilan kredit dilembaga perkreditan desa "marto nugroho" desa rowomarto kecamatan patianrowo kabupaten nganjuk, 2) Menganalisis pengaruh lokasi terhadap keputusan pengambilan kredit dilembaga perkreditan desa "marto nugroho" desa rowomarto kecamatan patianrowo kabupaten nganjuk, 3) menganalisis word of mouth dan lokasi terhadap keputusan pengambilan kredit dilembaga perkreditan desa "marto nugroho" desa rowomarto kecamatan patianrowo kabupaten nganjuk. Populasi dalam penelitian ini adalah seluruh nasabah aktif dan non aktif lembaga perkreditan desa "marto nugroho yang berjumlah 150 orang. Jumlah sampel yang digunakan adalah 60 responden dengan teknik penentuan sampel menggunakan rumus Slovin. pengambilan data dengan menggunakan kuisioner. Teknik analisa data menggunakan analisis regresi linier berganda dengan uji t untuk menganalisis pengaruh parsial dan uji $\mathrm{F}$ untuk menganalisis pengaruh simultan. Berdasarkan analisis tersebut diperoleh bahwa tingkat signifikan uji F sebesar $0,000(p<0,05)$, hal ini berarti word of mouth dan lokasi berpengaruh signifikan terhadap keputusan pengambilan kredit di lembaga perkreditan desa "marto nugroho" desa rowomarto kecamatan patianrowo kabupaten nganjuk. Disisi lain berdasarkan hasil uji $t$ dapat diketahui bahwa secara parsial word of mouth berpengaruh signifikan terhadap keputusan pengambilan kredit di lembaga perkreditan desa "marto nugroho" desa rowomarto kecamatan patianrowo kabupaten nganjukt signifikansi 0,000 $(\mathrm{p}<0,05)$. Sedangkan lokasi secara parsial juga berpengaruh signifikan terhadap keputusan pengambilan kredit di lembaga perkreditan desa "marto nugroho" desa rowomarto kecamatan patianrowo kabupaten nganjuk dengan nilai signifikansi uji t sebesar 0,000 ( $p>0,05)$. Variabel word of mouth lebih dominan berpengaruh karena nilai beta lebih besar dibanding variabel lokasi yaitu 0,466 .
\end{abstract}

\section{ABSTRACT}

This study aims to 1) Analyze the effect of word of mouth on credit decision making at the institution of village credit "marto nugroho" rowomarto village patianrowo sub-district nganjuk regency, 2) Analyze the influence of location on credit decision making at the village credit institution "marto 
nugroho" rowomarto village patianrowo district nganjuk, 3) analyze word of mouth and location for decision to take credit at the village credit institution "marto nugroho" rowomarto village, patianrowo sub-district nganjuk district. The population in this study were all active and non-active rural credit institutions "marto nugroho which numbered 150 people. The number of samples used was 60 respondents with sample determination techniques using Slovin formula. retrieval of data using questionnaires. Data analysis techniques using multiple linear regression analysis with $\mathrm{t}$ test to analyze the influence of partial and $\mathrm{F}$ test to analyze simultaneous influence. Based on the analysis it was found that the significant level of the $F$ test was $0,000(\mathrm{p}$ $<0.05$ ), this means that word of mouth and location had a significant effect on the decision to take credit in the village credit institution "Marto Nugroho" rowomarto village in Patianrowo sub-district Nganjuk district. On the other hand based on the results of the t test it can be seen that partially word of mouth has a significant effect on the decision to take credit in the village credit institution "marto nugroho" rowomarto village in the district of Patianrowo district, the significance is $0,000(p<0.05)$. While the location partially also has a significant effect on the decision to take credit in the village credit institution "Marto Nugroho" rowomarto village, Patianrowo sub-district, Nganjuk, with a significance value of $t$ test of $0.000(p>0.05)$. Word of mouth variables are more dominant because the beta value is greater than the location variable which is 0.466 .

\section{PENDAHULUAN}

Proses literasi masyarakat terhadap lembaga keuangan bisa dilakukan dengan menggunakan berbagai cara, dengan mendatangi langsung ke lokasi maupun bertanya kepada sanak saudara yang lebih mengetahui. Sebagian masyarakat lebih yakin jika bertanya kepada teman, tetangga maupun kerabat dekat hal ini bisa menguatkan mereka untuk menambah referensi tentang lembaga keuangan sehingga lebih yakin untuk menjadi nasabah pada lembaga keuangan tersebut. secara teori inilah yang disebut dengan pemasaran dari mulut ke mulut atau "word of mouth".

Menurut Tjiptono (2006:164) mengemukakan bahwa word of mouth merupakan pernyataan (secara personal maupun non personal) yang disampaikan oleh orang lain selain penyedia layanan kepada pelanggan. Word of mouth bersifat kredibel dan efektif karena disampaikan oleh orang-orang yang dipercayai konsumen (teman, 
keluarga, tetangga, dan sebagainya). Pada umumnya masyarakat akan lebih yakin

jika yang memberikan informasi tersebut adalah orang yang dia kenal baik, seperti saudara, tetangga dekat dan sebagainya dimana orang tersebut juga sudah menjadi nasabah dilembaga keuangan yang bersangkutan. Sehingga mereka akan lebih yakin dalam mengambil keputusan untuk kredit dilembaga keuangan. Sehingga bisa dikatakan bahwa pemasaran menggunakan metode "word of mouth" lebih efektif dan langsung mengena sasaran. Hal ni sejalan dengan penelitian dari setyaningsih (2017) yang menyimpulkan bahwa word of mouth (WOM) berpengaruh positrif dan signifikan terhadap keputusan nasabah dalam menggunakan e-banking bank BNI.

Menurut Babin, Barry J; Lee, Yong-Kie; Kim, Eun-Fu; dan Griffin,Mitch (2005) indikator word of mouth adalah, 1) Kemauan konsumen dalam membicarakan halhal positif tentang kualitas produk kepada orang lain. 2) Rekomendasi produk kepada orang lain. 3) Dorongan terhadap teman atau relasi untuk melakukan transaksi atas produk. Ketiga hal ini dapat digunakan untuk mengukur efektifitas dari pada word of mouth dalam mempengaruhi orang lain untuk mengambil keputusan dalam memilih produk dan jasa khususnya yang terkait dengan kredit pada lembaga keuangan.

Pertimbangan lain yang digunakan orang dalam memilih lembaga keuangan adalah faktor lokasi dimana keberadaan lembaga keuangan yang mendekati tempat tinggal mereka menjadi salah satu alasan utama mereka dalam memilih lembaga keuangan tersebut. oleh karena itu saat ini banyak lembaga keuangan yang berada diwilayah pedesaan bahkan sampai menjangkau pelosok desa. Tidak terkecuali bank umum sendiri yang sudah mulai mendirikan kantor unitnya sampai ke pelosok pedesaan. Masyarakat semakin dimanjakan oleh banyak pilihan jika membutuhkan kredit. Mereka tidak perlu jauh-jauh datang ke pusat perkotaan untuk mendapatkan fasilitas kredit karena semuanya sudah tersedia disekitar tampat tinggal mereka. lokasi menjadi faktor yang sangat penting bagi lembaga keuangan dalam mendorong masyarakat untuk bisa mengakses kredit secara langsung.

Menurut Lupiyoadi (2013:96) “Lokasi merupakan keputusan yang dibuat perusahaan berkaitan dengan dimana operasi dan stafnya akan ditempatkan". Dalam pemilihan lokasi tentunya harus diiringi dengan beberapa hal yaitu letak 

pemukiman penduduk sekitar, tersedianya lahan parkir yang memadai dan lainnya. Lokasi yang strategis tentu dapat menarik banyak calon nasabah untuk datang ke bank atau lembaga keuangan non bank yang ada disekitarnya. Indikator lokasi menurut Tjiptono (2006:41) diantaranya adalah akses, visibilitas, lalu lintas (tingkat kepadatan dan banyaknya orang), tempat parkir yang luas dan ekspansi. Oleh karena setiap lembaga keuangan harus pandai dalam memilih lokasi untuk membuka cabang atau kantor kas yang dapat menjangkau masyarakat terutama diwilayah pedesaan. pada intinya bahwa lokasi dapat mempengaruhi masyarakat untuk memutuskan mengamil kredit pada lembaga keuangan hal ini sejalan dengan penelitian dari Santosa dan Raharjo (2015) yang menyimpulkan bahwa lokasi berpengaruh signifikan terhadap keputusan pembelian di toko bangunan kalilicik Demak.

Kedua faktor diatas yaitu word of mouth dan lokasi dapat digunakan sebagai rujukan bagi calon nasabah dalam memilih lembaga keuangan. Masyarakat harus mampu mengambil keputusan dengan tepat dan segera. Sehingga kebutuhan mereka terkait dengan keuangan untuk modal usaha atau mencukupi kebutuhan lainnya segera dapat dipenuhi. Menurut Kotler dan Amstrong (2016:177) Keputusan pembelian merupakan bagian dari perilaku konsumen perilaku konsumen yaitu studi tentang bagaimana individu, kelompok, dan organisasi memilih, membeli, menggunakan, dan bagaimana barang, jasa, ide atau pengalaman untuk memuaskan kebutuhan dan keinginan mereka. Calon nasabah tentu memiliki pengalaman tersendiri yang digunakan untuk memilih lembaga keuangan yang diperoleh dari saudara, tetangga dan teman mereka. biasanya banyak orang memilih lembaga keuangan dengan persyaratan yang mudah dan proses pencairan yang cepat, namun adalah juga yang melihat suku bunga kredit ang ditawarkan karena banyak lembaga keuangan yang menawarkan kredit dengan suku bunga yang rendah. Proses pengambilan keputusan yang dilakukan oleh calon nasabah biasanya melalui beberapa tahap. Menurut Kotler dan Amstrong (2016:174) tahapan dalam pengambilan keputusan meliputi 1) timbulnya kebutuhan, 2) pencarian informasi, 3) 

pengambilan kredit.

Lembaga Perkreditan Desa “Marto Nugroho" yang ada di Desa Rowomarto, Kecamatan Patianrowo, Kabupaten Nganjuk Jawa Timur sudah berdiri kurang lebih 2 tahun dibawah naungan Badan Usaha Milik Desa (Bumdes) setempat. Unit usaha ini bergerak dibidang simpan pinjam ibu rumah tangga. LKM ini sudah memiliki kurang lebih 150 nasabah peminjam dengan plafond pinjaman kisaran Rp.500.000,sampai dengan Rp 5.000.000,- jumlah nasabah yang lumayan banyak tidak terlepas dari pelayanan yang diberikan oleh petugas lembaga perkreditan desa sehingga masyarakat yang merasa puas dengan layanan dan produk keuangan tersebut akan merekomendasikan tetangganya untuk menjadi nasabah kredit pada lembaga perkreditan tersebut. disisi lain persyaratan untuk kredit juga tidak terlalu sulit hanya menggunakan kartu tanda penduduk (KTP) saja dan pengikatan kreditnya hanya bedasarkan saling percaya antara petugas dan calon nasabah. kemampuan word of mouth dan ditunjang dengan lokasi lembaga perkreditan ini diharapkan mampu untuk terus menarik calon nasabah disekitar desa tersebut untuk menjadi nasabah kredit.

Adapun tujuan penelitian ini adalah (1) Menganalisis pengaruh word of mouth terhadap keputusan mengambil kredit di lembaga perkreditan desa "marto nugroho" Desa Rowomarto, Kec. Patianrowo Kabupaten Nganjuk (2) Mengabalisis pengaruh lokasi terhadap keputusan mengambil kredit di lembaga perkreditan desa "marto nugroho" Desa Rowomarto, Kec. Patianrowo Kabupaten Nganjuk (3) Menganalisis pengaruh word of mouth dan lokasi terhadap keputusan mengambil kredit di lembaga perkreditan desa "marto nugroho" Desa Rowomarto, Kec. Patianrowo Kabupaten Nganjuk

\section{METODOLOGI PENELITIAN}

\section{Rancangan Penelitian}

Penelitian ini merupakan penelitian deskriptif dengan pendekatan kuantitatif. Pendekatan kuantitatif adalah metode penelitian yang berdasarkan sifat positivisme yang digunakan untuk meneliti pada populasi atau sampel tertentu. Pengumpulan 
data menggunakan instrumen kuisioner. Analisis data bersifat kuantitatif/statistik dengan tujuan untuk menguji hipotesis yang telah ditetapkan (Sugiyono, 2012:8).

Penelitian ini dilakukan lembaga perkreditan desa "marto nugroho" di Desa Rowomarto Kecamatan Patianrowo Kabupaten Nganjuk. Populasi dalam penelitian ini adalah seluruh nasabah aktif dan non aktif yang meminjam di lembaga perkreditan desa "marto nugroho" dengan jumlah 150 nasabah. dari jumlah tersebut peneliti hanya mengambil sebagian untuk dijadikan sampel.

Menurut Juliansyah Noor (2012:158) Untuk mendapatkan sampel yang representatif dan lebih pasti peneliti menggunakan formula slovin dengan perkiraan kesalahan sebesar $10 \%$, yaitu sebagai berikut :

$$
\mathrm{n}=\frac{N}{1+(N \times e 2)}
$$

Dimana:

$$
\begin{aligned}
& \mathrm{n}=\text { Sampel } \\
& \mathrm{N}=\text { Populasi } \\
& \mathrm{e}=\text { error level (tingkat kesalahan) } 10 \% \text { atau } 0,1
\end{aligned}
$$

Perhitungannya adalah sebagai berikut.

$$
\begin{aligned}
& \mathrm{n}=\frac{150}{1+\left(150 \times 0,1^{2}\right)} \\
& \mathrm{n}=\frac{150}{1+(150 \times 0,01)} \\
& \mathrm{n}=\frac{150}{1+(1,5)} \\
& \mathrm{n}=\frac{150}{2,5} \\
& \mathrm{n}=60 \text { nasabah. }
\end{aligned}
$$

Adapun hipoesis dalam penelitian ini adalah sebagai berikut :

$\mathrm{H}_{1}$ : Diduga word of mouth berpengaruh signifikan terhadap keputusan mengambil kredit di lembaga perkreditan "marto nugroho" di Desa Rowomarto Kec. Patianrowo Kabupaten Nganjuk. 
$\mathrm{H}_{2}$ : Diduga lokasi berpengaruh signifikan terhadap keputusan mengambil kredit di lembaga perkreditan "marto nugroho" di Desa Rowomarto Kec. Patianrowo Kabupaten Nganjuk.

$\mathrm{H}_{3}$ : Diduga word of mouth dan lokasi berpengaruh signifikan terhadap keputusan mengambil kredit di di lembaga perkreditan "marto nugroho" di Desa Rowomarto Kec. Patianrowo Kabupaten Nganjuk.

\section{Teknik Analisis Data}

Merupakan proses penyederhanaan data kedalam bentuk yang lebih mudah dibaca dan diinterpretasikan. Dalam proses ini seringkali digunakan statistic. Fungsi pokok statistic adalah untuk menyederhanakan data penelitian, selain fungsinya memungkinkan peneliti untuk menguji apakah ada hubungan antar variabel (Efendi\&Tukiran, 2012:45). Karena dalam penelitian ini variabel bebasnya lebih dari satu maka digunakan analisis regresi linier berganda. Model analisis regresi linier berganda yang digunakan untuk menguji hipotesis adalah sebagai berikut :

$$
Y=b_{0}+\beta_{1} X_{1}+\beta_{2} X_{2}+e
$$

Dimana ;

$$
\begin{aligned}
& \mathrm{b}_{0}=\text { konstanta } \\
& \beta_{1}=\text { Koefisien regresi untik } \mathrm{X} 1 \\
& \beta_{2}=\text { Koefisien regresi untuk } \mathrm{X} 2 \\
& \mathrm{Y}=\text { Keputusan pengambilan kredit } \\
& \mathrm{X}_{1}=\text { Word Of Mouth } \\
& X_{2}=\text { Lokasi } \\
& \mathrm{e}=\text { standar error }
\end{aligned}
$$

\section{HASIL DAN PEMBAHASAN}

\section{Hasil Uji Asumsi Klasik}

a. Uji normalitas

hasil uji normalitas dalam penelitian ini adalah sebagai berikut: 
Gambar 1

Uji Normalitas

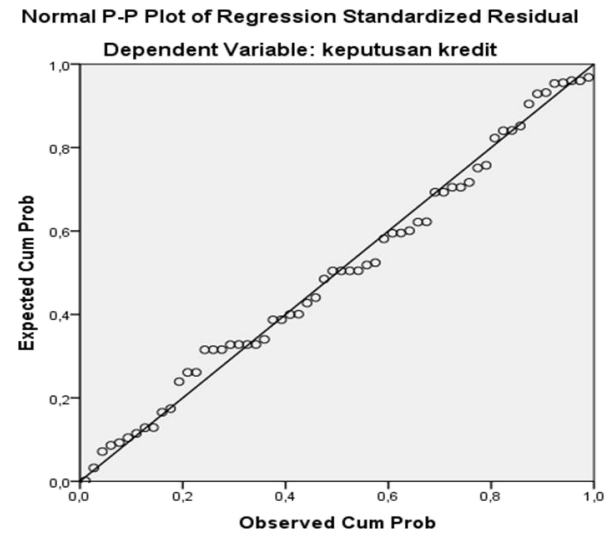

Dari gambar diatas dapat diketahui bahwa titik-titik menyebar disekitar garis diagonal serta memiliki arah yang mengikuti garis diagonal, sehingga dapat disimpulkan bahwa model regresi layak dipakai untuk memprediksi keputusan pengambilan kredit di lembaga perkreditan rakyat "marto nugroho" Desa Rowomarto, Kecamatan Patianrowo Kabupaten Nganjuk berdasarkan masukan variabel-variabel bebasnya.

\section{b. Uji Multikolinieritas}

hasil uji multikolinieritas dalam penelitian ini adalah sebagai berikut

Gambar 2

Uji Multikolinieritas

\begin{tabular}{|ll|r|r|}
\hline \multirow{2}{*}{ Model } & \multicolumn{2}{|c|}{ Collinearity Statistics } \\
\cline { 3 - 4 } & & Tolerance & \multicolumn{1}{c|}{ VIF } \\
\hline 1 & (Constant) & & \\
& X1 & & 1.358 \\
& & & \\
& &
\end{tabular}

Pengaruh Word Of Mouth Dan Lokasi Terhadap Keputusan Mengambil Kredit Di Lembaga Perkreditan Desa "Marto Nugroho" Desa Rowomarto Kecamatan Patianrowo Kabupaten Nganjuk 
(Sumber: data primer diolah, 2019)

Berdasarkan pada Tabel di atas dapat dilihat bahwa kedua variabel bebas memiliki nilai VIF lebih kecil dari 10, dengan demikian dapat disimpulkan bahwa semua variabel bebas yang diteliti tidak saling berhubungan atau (non multikolinieritas).

\section{c. Uji Heteroskedastisitas}

hasil uji heteroskedastisitas dalam penelitian ini adalah sebagai berikut.

Gambar 3

\section{Uji Heterokedastisitas}

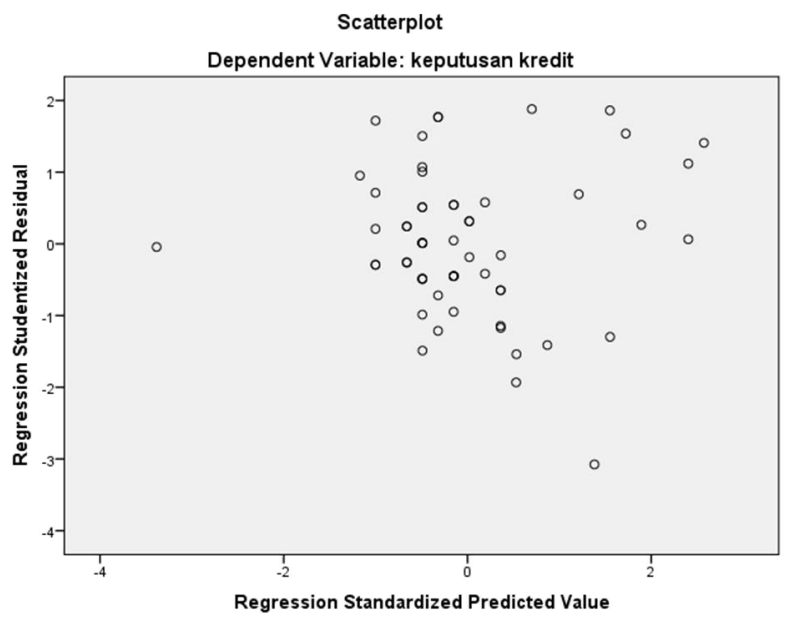

Sumber data: Data diolah

Berdasarkan Gambar di atas dapat disimpulkan bahwa tidak terjadi heteroskedastisitas.

\section{Hasil Analisis Regresi Berganda}

Analisis regresi dilakukan untuk membuktikan hipotesis yang diajukan dalam penelitian ini, yakni untuk menganalisis pengaruh antara variabel bebas terhadap variabel terikat, baik secara parsial maupun secara simultan serta untuk menguji hipotesis penelitian yang telah dikemukakan sebelumnya. Variabel bebas dalam penelitian adalah word of mouth dan lokasi, sedangkan variabel terikatnya adalah Keputusan pengambilan kredit. 
Gambar 4.

Regresi linier bergnda

\begin{tabular}{|l|l|r|r|r|}
\hline \multicolumn{2}{|c|}{} & \multicolumn{2}{|c|}{$\begin{array}{c}\text { Unstandardized } \\
\text { Coefficients }\end{array}$} & $\begin{array}{c}\text { Standar } \\
\text { dized Coefficients }\end{array}$ \\
\cline { 2 - 5 } Model & B & Std. Error & Beta \\
\hline 1 & (Constant) & 9,486 & 2,729 &, 341 \\
\cline { 2 - 5 } & X1 &, 466 &, 124 &, 577 \\
\cline { 2 - 5 } & X2 &, 464 &, 073 & \\
\hline
\end{tabular}

(Sumber : hasil olah SPSS, 2019)

Berdasarkan Tabel atas, maka didapat persamaan regresi linier berganda sebagai berikut:

$$
Y=9,486+0,466 X_{1}+0,464 X_{2}+e
$$

persamaan regresi tersebut mempunyai makna sebagai berikut :

a. Konstanta $=9,486$

Jika variabel word of mouth $\left(\mathrm{X}_{1}\right)$ dan lokasi $\left(\mathrm{X}_{2}\right)=0$, maka keputusan pengambilan kredit $(Y)$ memiliki nilai sebesar 9,486

b. Koefisien $X_{1}=0,466$

Setiap penambahan 1 satuan pada variabel word of mouth $\left(\mathrm{X}_{1}\right)$ dengan asumsi variabel lokasi $\left(\mathrm{X}_{2}\right)$ tetap dan tidak berubah, maka akan meningkatkan keputusan pengambilan kredit $(\mathrm{Y})$ sebesar 0,466 .

c. Koefisien $\mathrm{X}_{2}=0,464$

Setiap penambahan 1 satuan pada variabel lokasi $\left(\mathrm{X}_{2}\right)$ dengan asumsi variabel word of mouth $\left(\mathrm{X}_{1}\right)$ tetap dan tidak berubah, maka akan meningkatkan keputusan pengambilan kredit $(\mathrm{Y})$ sebesar 0,464.

\section{Koefisien Determinasi $\left(\mathbf{R}^{2}\right)$}

Pengaruh Word Of Mouth Dan Lokasi Terhadap Keputusan Mengambil Kredit Di Lembaga Perkreditan Desa “Marto Nugroho" Desa Rowomarto Kecamatan Patianrowo Kabupaten Nganjuk

https:// doi.org/10.35457/akuntabilitas.v12i1.720

(C) 2019 Akuntabilitas: Jurnal Ilmu-Ilmu Ekonomi. Semua hak cipta dilindungi undang-undang 
Berikut hasil koefisien determinasi dari kedua variabel bebas, yaitu adalah word of mouth dan lokasi.

\begin{tabular}{|c|c|c|c|}
\hline \multicolumn{4}{|c|}{ Gambar 4} \\
\hline \multicolumn{4}{|c|}{ Detreminasi $\left(\mathrm{R}^{2}\right)$} \\
\hline Model & $\mathrm{R}$ & R Square & Adjusted R Square \\
\hline 1 & $807 a$ & 651 & 639 \\
\hline
\end{tabular}

(Sumber : Hasil olah SPSS, 2019)

Berdasarkan hasil analisis pada tabel diatas diperoleh nilai Adjusted $R$ Square sebesar 0,639. dengan demikian menunjukkan bahwa variabel word of mouth dan lokasi dapat menjelaskan keputusan pengambilan kredit 63,9\% sisanya sebesar 36,1\% tidak dijelaskan dalam penelitian ini.

\section{Hasil Pengujian Secara Parsial (Uji t)}

Berikut hasil pengujian secara parsial menggunakan uji t yang nilainya akan dibandingkan dengan signifikansi 0,05 atau 5\%.

\section{Gambar 5}

Uji $\mathrm{t}$

\begin{tabular}{|c|c|c|c|c|c|c|}
\hline \multirow{2}{*}{\multicolumn{2}{|c|}{ Model }} & \multicolumn{2}{|c|}{$\begin{array}{l}\text { Unstandardized } \\
\text { Coefficients }\end{array}$} & \multirow{2}{*}{$\begin{array}{c}\text { Standardized } \\
\text { Coefficients } \\
\text { Beta } \\
\end{array}$} & \multirow[b]{2}{*}{$\mathrm{t}$} & \multirow[b]{2}{*}{ Sig. } \\
\hline & & B & Std. Error & & & \\
\hline \multirow[t]{3}{*}{1} & (Constant) & 9,486 & 2,729 & & 3,476 & 001 \\
\hline & $\begin{array}{l}\text { word of } \\
\text { mouth }\end{array}$ & 466 & 124 & 341 & 3,744 & , 000 \\
\hline & lokasi & 464 & ,073 & ,577 & 6,333 & ,000 \\
\hline
\end{tabular}

(Sumber: Hasil olah SPSS, 2019)

Berdasarkan tabel diatas dapat diketahui bahwa nilai signifikansi variabel word of mouth adalah 0,000 < 0,05 yang artinya Ho ditolak dan H1 diterima sehingga dapat disimpulkan bahwa word of mouth berpengaruh signifikan terhadap keputusan pengambilan kredit. Nilai dignifikansi untuk variabel lokasi sebesar 0,000<0,05 
yang artinya Ho ditolak dan H1 sehingga dapat disimpulkan bahwa lokasi berpengaruh terhadap keputusan pengambilan kredit.

\section{Hasil Pengujian Secara Simultan (Uji F)}

Berikut hasil pengujian secara simultan menggunakan uji $\mathrm{F}$ yang nilainya akan dibandingkan dengan signifikansi 0,05 atau 5\%.

\section{Gambar 6}

\begin{tabular}{|c|c|c|c|c|c|c|}
\hline \multicolumn{7}{|c|}{ ANOVA $^{a}$} \\
\hline \multirow{2}{*}{\multicolumn{2}{|c|}{ Model }} & Sum of & & Mean & & \\
\hline & & Squares & df & Square & $\mathrm{F}$ & Sig. \\
\hline \multirow[t]{3}{*}{1} & Regression & 439,708 & 2 & 219,854 & 53,264 &, $000^{\mathrm{b}}$ \\
\hline & Residual & 235,275 & 57 & 4,128 & & \\
\hline & Total & 674,983 & 59 & & & \\
\hline
\end{tabular}

a. Dependent Variable: keputusan kredit

b. Predictors: (Constant), lokasi, word of mouth

(Sumber : hasil olah SPSS, 2019)

Berdasarkan tabel diatas dapat diketahui bahwa nilai F tabel adalah 53,264 > 3,15 ( $\left.\mathrm{F}_{\text {tabel }}\right)$ dengan tingkat signifikansi 0,000 < 0,05 yang berarti Ho ditolak dan H1 diterima sehingga dapat disimpulkan bahwa secara simultan variabel word of mouth dan lokasi berpengaruh signifikan terhadap keputusan pengambilan kredit.

\section{KESIMPULAN}

1. Word of Mouth secara parsial berpengaruh signifikan terhadap keputusan pengambilan kredit di lembaga perkreditan desa "marto nugroho" desa rowomarto kecamatan patianrowo kabupaten nganjuk.

2. Lokasi secara parsial berpengaruh signifikan terhadap keputusan pengambilan kredit di lembaga perkreditan desa "marto nugroho" desa rowomarto kecamatan patianrowo kabupaten nganjuk.

3. Word of Mouth dan Lokasi secara simultan berpengaruh signifikan terhadap keputusan pengambilan kredit di lembaga perkreditan desa "marto nugroho" desa rowomarto kecamatan patianrowo kabupaten nganjuk. 


\section{DAFTAR PUSTAKA}

Babin, J. Barry, Yong-Ki Lee, Eun-Ju Kim, Mitch Griffin.2005. Modelling Consumer satisfaction an word-of-mouth: restaurant patronage in korea. Journal of service marketing vol 19, p133-139.

Efendy, S \& Tukiran, 2012. Metode penelitian survei. Edisi Alfabeta, Bandung.

Juliansyah, Noor 2012. Metodologi penelitian Skripsi, Thesis dan Disertasi Karya Ilmiah. Cetakan Kedua. Jakarta: Kencana Prenada Media

Kotler, Philip and Gary Amstrong. 2016. Prinsip-prinsip Pemasaran. Edii13. Jilid 1. Jakarta:Erlangga

Lupiyoadi, Rambat. 2013. Manajemen pemasaran jasa. Jakarta: Salemba Empat.

Santosa, B,S dan Raharjo,K. 2015. Analisis pengaruh lokasi, kualitas pelayanan dan persepsi harga terhadap keputusan pembelian di toko bangunan rajawali kalilicik Demak. Diponegoro of Journal Management. Vol 4 no.4 ISSN :2337-3792

Setyaningsih, D, E. 2017. Pengaruh kualitas layanan dan word of mouth melalui minat terhadap keputusan nasabah dalam menggunakan e-banking pada bank BNI. Jurnal Ekonomi Bisnis Vol 22 No.1 ISSN 0853-862X Universitas Gunadarma

Sugiyono. 2012. Metode penelitian kantitatif dan R\&D Bandung: Alfabeta.

Tjiptono, Fandy. 2006. Manajemen jasa. Edisi pertama. Yogyakarta : Andi 